\title{
PENINGKATAN HASIL BELAJAR SUBTEMA RUKUN DALAM PERBEDAAN MELALUI MODEL MAKE A MATCH PADA PEMBELAJARAN TEMATIK DI SEKOLAH DASAR
}

\author{
Nashran Azizan \\ Institut Agama Islam Negeri Padangsidimpuan, Indonesia \\ E-mail: nashran_azizan@yahoo.com
}

The low learning outcomes was caused by the lack of teacher's creativity in applying a learning model when the learning process took place. The purpose of this study was to show variations in learning in order to achieve optimal learning outcomes. This research used Classroom Action Research by applying 4 phases, namely planning, implementing, observing, and reflecting. The study result explained that there was an increase in teacher's activity $73,25 \%$ and student activity $74,5 \%$. Then the learning outcomes of students in cycle I got $55,43 \%$ and cycle II got $84,78 \%$. This meant an increase of $29,35 \%$. Obtaining these results could be concluded that the application of the make a match model could improve activities and outcomes of student's learning in the thematic subjects in harmonious sub-themes in sixth grade MIN 3 city Medan academic year 2019/2020.

Keywords: Learning outcome, Make a match model, Thematic learning

\section{PENDAHULUAN}

Berdasarkan hasil observasi yang dilaksanakan terhadap proses pembelajaran di kelas VI Madrasah Ibtidaiyah Negeri (MIN) 3 kota Medan ditemukan masalah yakni, hasil belajar siswa yang terlihat rendah. Rendahnya motivasi belajar terhadap siswa serta peran siswa di saat proses pembelajaran berlangsung masih kurang diminati. Padahal dalam pembelajaran tematik seharusnya ada keaktifan yang perlu dilakukan siswa sehingga bukan hanya mahir dalam pengetahuan, tetapi juga mahir dalam keterampilan.

Permasalahan disebabkan oleh beberapa hal, yaitu guru kurang memiliki kemampuan dalam mendesain perangkat pembelajaran yang di dalamnya terdapat model-model menarik minat belajar terungkap rendah sehingga materi yang disampaikan terlihat membosankan bagi siswa. Selain itu guru selalu membiasakan mengajar hanya ceramah dan tanya jawab, hasilnya siswa terlihat jenuh untuk belajar. Inilah yang menjadi faktor rendahnya hasil belajar siswa pada mata pelajaran tematik. 
Pembelajaran tematik hendaknya lebih menekankan kepada pendalaman konsep materiya, sehingga penyampaian pengetahuan tercapai secara maksimal. Namun, keinginan yang diharapkan tidak sesuai realita di lapangan.

Berdasarkan permasalahan di atas, akibat kompetensi guru yang masih rendah tersebut, menimbulkan hasil belajar siswa MIN 3 kota Medan kurang optimal dan belum sesuai harapan. Maka untuk meningkatkan hasil belajar siswa pada mata pelajaran tematik perlu diterapkannya suatu model pembelajaran guna menjadikan suasana tidak seperti heningan tanpa arti. Adapun model pembelajaran yang dianggap dapat membantu dalam mengatasi suatu masalah tersebut yaitu dengan menggunakan model make a match, model ini diyakini sangat efektif untuk diterapkan dalam penyampaian materi. Make a match dikembangkan oleh Lorna Curran, model ini menuntut siswa untuk belajar aktif dengan melakukan kegiatan mencari pasangan, antara soal dan jawaban yang disediakan oleh guru.

Adapun maksud dari model pembelajaran make a match merupakan cara belajar mengajar yang mengutamakan penanaman kompetensi sosial terutama kemampuan bekerja sama, kemampuan berinterakasi di samping kemampuan berpikir cepat melalui permainan mencari partner yang dibantu dengan kartu. Model pembelajaran make a match (mencari partner) merupakan salah satu preferensi yang dapat diimplementasikan pada siswa. Hal ini sependapat yang dinyatakan oleh Yatim (Wandy, 2017, h. 111), bahwa make a match merupakan suatu model pembelajaran dengan cara menemukan sepenggal kartu yang berisi soal dan sepenggal lagi berisi jawaban, artinya siswa mencari kartu yang berisi soal dan siswa lainnya mencari kartu yang berisi jawaban. Pendapat tersebut dibenarkan Fauzi dkk (Kaharuddin, 2018, h. 14) mengatakan bahwa model make a match sangat layak diterapkan pada pembelajaran di sekolah dasar, karena memiliki kelebihan yaitu siswa mencari partner sambil belajar tentang konsep atau tema dalam suasana yang mengasyikkan. Oleh sebab itu, model pembelajaran make a match ini amat membantu guru untuk merangkaikan materi pembelajaran dengan berbagai sumber yang terdapat di lingkungan sekitar serta memberikan suasana baru bagi siswa, sehingga menimbulkan pembelajaran yang menarik minat siswa untuk belajar. Dikatakan sebagai pembelajaran yang dapat menarik minat siswa untuk belajar, karena dalam menerapkan model ini terdapat langkah-langkah yang perlu dipahami sebagai berikut:

1. Buatlah potongan-potongan kertas sejumlah banyaknya siswa yang berada di dalam kelas.

2. Bagilah jumlah kertas-kertas tersebut menjadi dua bagian yang sama. 
3. Tulis pertanyaan tentang materi yang telah diberikan sebelumnya pada setengah bagian kertas. Setiap kertas berisi satu pertanyaan.

4. Pada separuh kertas yang lain, tulis jawaban dari pertanyaan-pertanyaan yang telah dibuat.

5. Kocoklah semua kertas sehingga akan tercampur antara soal dan jawaban.

6. Berikan setiap kertas kepada siswa satu potongan kertas. Jelaskan kepada mereka bahwa ini merupakan aktivitas yang dilakukan berpasangan. Selanjutnya siswa akan mendapatkan potongan kertas berisi pertanyaan dan sepotongnya lagi berisi jawaban.

7. Mintalah kepada siswa untuk menemukan pasangan antara soal dan jawaban.

8. Setelah menemukan, siswa diberikan waktu untuk berdiskusi.

9. Kemudian siswa menyampaikan hasil diskusi di depan kelas (Siregar \& Hatika, 2019, h. 10).

Adapun kelebihan-kelebihan yang terdapat pada model make a match menurut Shoimin (Tiyasa, 2018, h. 15), yaitu: (1) suasana keceriaan akan lahir dalam proses pembelajaran, (2) kerja sama siswa tercipta dengan energik, (3) timbulnya semangat gotong-royong yang merata oleh seluruh siswa.

Berdasarkan beberapa hasil penelitian terdahulu, model make a match dinyatakan mampu mendongkrak hasil belajar siswa. Penelitian yang dilakukan oleh Aliputri (2018) yang menunjukkan bahwa penerapan model pembelajaran make a match berbantuan kartu bergambar dapat meningkatkan hasil belajar siswa sebesar 51\% kondisi di awal, selanjutnya meningkat di siklus I sebesar $90 \%$ dan mengalami peningkatan pada siklus II menjadi 94\%. Penelitian serupa juga dilakukan oleh Isnarofik (2017) yang menyatakan bahwa model make a match dapat meningkatkan rasa ingin tahu dan prestasi belajar siswa dengan memperoleh nilai $30 \%$ di siklus I dan $81,5 \%$ di siklus II. Kemudian penelitian yang sama juga dilakukan oleh Nurainun Harahap (2017) menunjukkan bahwa model pembelajaran kooperatif tipe make a match dapat meningkatkan hasil belajar siswa kelas IV SD Negeri 168432 kota Tebing Tinggi dengan memperoleh nilai ketuntasan sebesar $42 \%$ di siklus I dan $55 \%$ di siklus II serta meningkat di siklus II dengan nilai $87 \%$.

Tujuan penelitian ini dilaksanakan untuk memberikan variasi model pembelajaran dalam usaha meningkatkan hasil belajar siswa kelas 6 MIN 3 kota Medan. Karena berdasarkan penelusuran di lapangan menunjukkan bahwa hasil belajar siswa 
yang rendah disebabkan karena guru belum melakukan model pembelajaran dalam kegiatan mengajar.

\section{METODE PENELITIAN}

Penelitian ini memakai metode classroom action research atau biasa disebut penelitian tindakan kelas (PTK). Metode penelitian ini diimplementasikan atau penindakan yang dilaksanakan di dalam kelas atau di luar kelas dengan tujuan membenahi dan meningkatkan sistem pembelajaran menjadi lebih baik. Langkahlangkah dalam penelitian tindakan kelas dilaksanakan melalui siklus dan dirancang menjadi empat langkah. Empat langkah yang dimaksud menurut Kurt Lewin (Kunandar, 2011, h. 42), yaitu: (1) perencanaan, (2) tindakan, (3) pengamatan, (4) refleksi. Artinya, dalam pelaksanaan penelitian PTK perlu merencanakan suatu pemecahan masalah yang ditemukan. Kemudian rencana tersebut diterapkan sebagai suatu tindakan, lalu tindakan tersebut diamati. Setelah diamati maka dilakukan refleksi, guna untuk menganalisis data yang ditemukan selama tindakan dan melihat sejauh mana pencapaian dalam memperoleh hasil baik, kemudian direvisi untuk melakukan tindakan ulang pada siklus selanjutnya.

Penelitian ini fokus pada pembelajaran tematik dengan tema persatuan dalam perbedaan subtema rukun dalam perbedaan di kelas 6 MIN 3 kota Medan, jumlah siswa sebanyak 23 siswa terdiri dari 11 siswa laki-laki dan 12 siswa perempuan dengan proses pembelajaran menerapkan model make a match. Penelitian bertujuan untuk memperbaiki cara pengajaran guru dalam meningkatkan hasil belajar siswa terhadap proses pembelajaran tematik.

Teknik pengumpulan data menggunakan: (1) Tes, yaitu perangkat cek yang dipakai untuk mengetahui atau menilai kemampuan siswa (Arikunto, 2005, h. 53). Tes yang diberikan berbentuk pilihan berganda dan diimplementasikan di setiap siklus; (2) observasi, yaitu dilakukan untuk mengamati objek penelitian (Salim \& Syahrum, 2012, h. 114). Observasi yang dimaksud ialah pengamatan terhadap seluruh kegiatan pembelajaran yang terjadi saat dilakukannya pemberian tindakan; (3) dokumentasi, yaitu dilakukan pengumpulan data sebagai pendukung untuk penguat keabsahan penelitian berupa dokumen maupun foto; (4) wawancara, yaitu digunakan untuk mencari data terkait masalah yang dihadapi guru dan siswa dalam memahami proses pembelajaran tematik, selain itu untuk mendapatkan data mengenai tanggapan siswa ataupun guru.

Teknik analisis data dalam penelitian ini dianalisis secara kuantitatif dan kualitatif, dengan menggunakan tes dan angket. Maka untuk melihat kesuksesan 
implementasi model make a match pada pembelajaran tematik dalam rangka meningkatkan hasil belajar siswa. Adapun rumus yang digunakan dalam mengolah data untuk menentukan hasil belajar siswa, yakni $\mathrm{KB}=-\times 100 \%$ dimana $\mathrm{KB}=$ ketuntasan belajar, $\mathrm{T}=$ jumlah skor yang diperoleh siswa, $\mathrm{T}_{1}=$ jumlah skor total (Murni, 2010, h. 35).

\section{HASIL PENELITIAN DAN PEMBAHASAN}

\section{Hasil Penelitian}

Berdasarkan hasil observasi telah ditemukan terkait aktivitas guru dan siswa dalam proses pembelajaran tematik dengan menerapkan model make a match, data dapat dilihat pada hasil observasi yang ditampilkan di bawah.

Diagram 1. Rekapitulasi Hasil Observasi Aktivitas Guru Siklus I

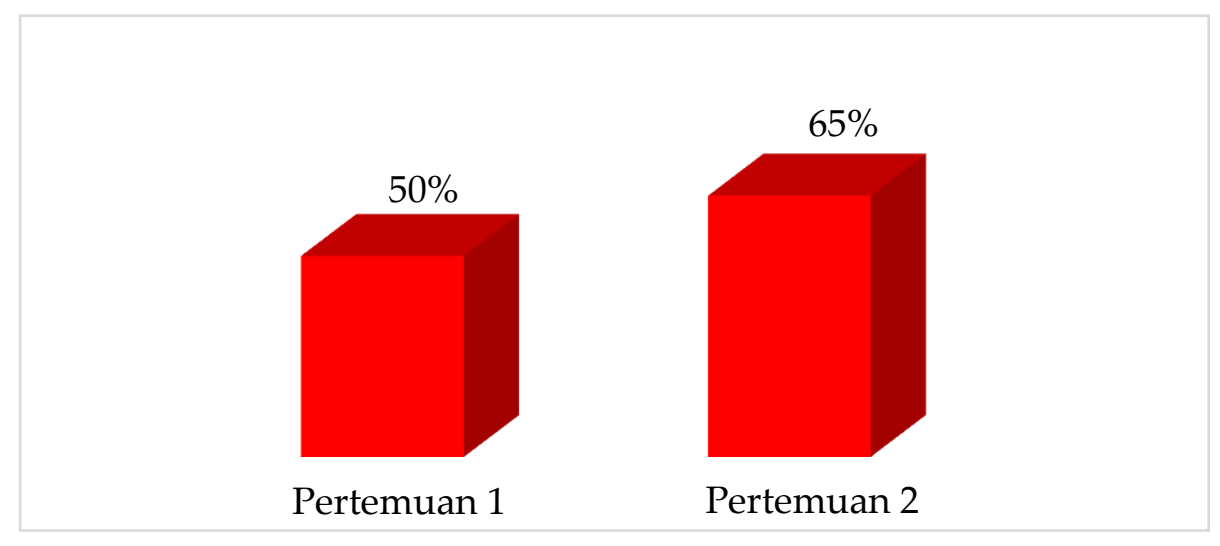

Berdasarkan diagram 1 di atas, hasil observasi di siklus I terlihat bahwa persentase aktivitas guru dalam proses pembelajaran tematik dengan menerapkan model make a match meraih nilai rata-rata $57,5 \%$ dan berada pada kategori cukup. Selanjutnya di siklus II, hasil observasi dapat dilihat pada diagram 2 di bawah.

Diagram 2. Rekapitulasi Hasil Observasi Aktivitas Guru Siklus II

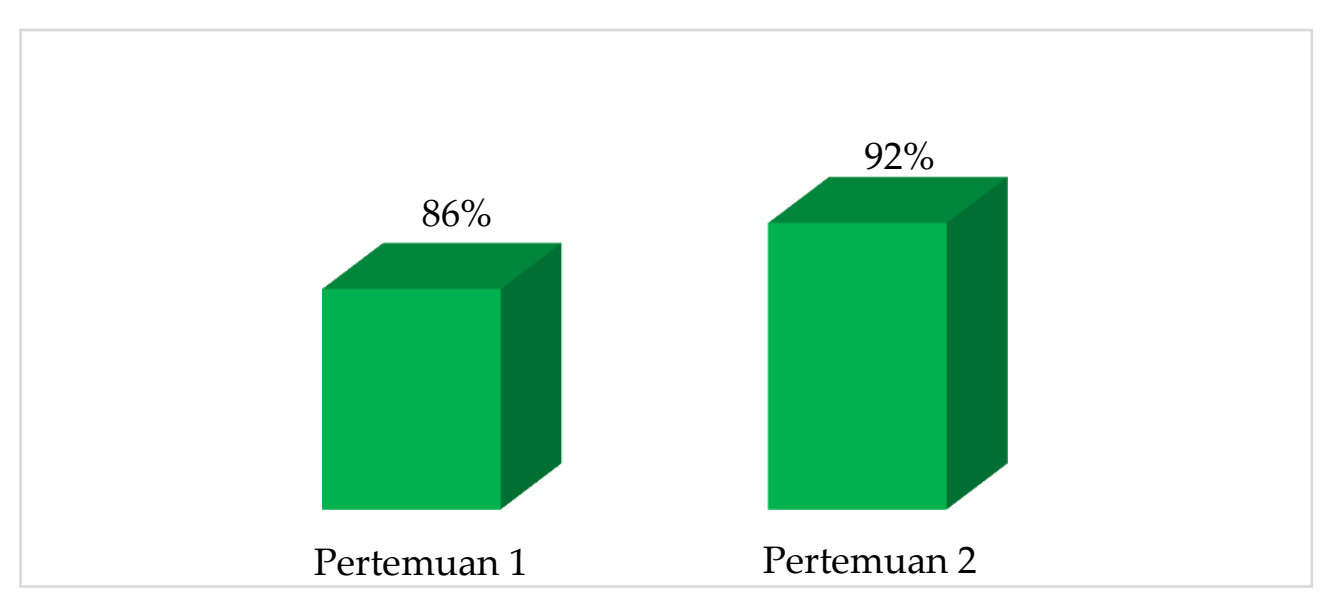


Berdasarkan diagram 2 di atas, terlihat bahwa persentase aktivitas guru dalam proses pembelajaran tematik menggunakan model make a match pada siklus II diperoleh nilai rata-rata sebesar $89 \%$ dan berada pada kategori sangat baik. Maka kesimpulan aktivitas guru pada pembelajaran tematik dengan menggunakan model make a match menghasilkan kegiatan yang baik.

Adapun perolehan dari hasil aktivitas belajar siswa dalam pembelajaran tematik menggunakan model make a match dapat dilihat pada diagram 3 di bawah.

Diagram 3. Rekapitulasi Hasil Observasi Aktivitas Siswa Siklus I

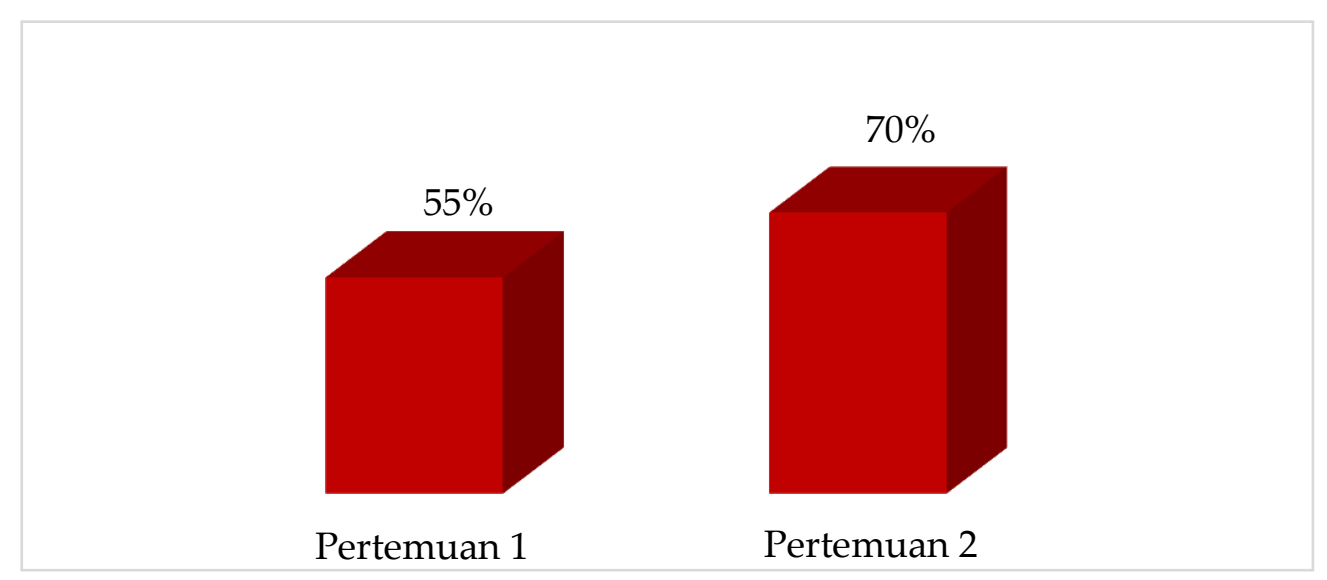

Berdasarkan diagram 3 di atas terlihat bahwa hasil observasi aktivitas belajar siswa pada siklus I memperoleh persentase nilai rata-rata sebesar 62,5\% dengan kategori cukup. Ini berarti siswa belum mencapai hasil yang diharapkan. Sedangkan hasil observasi aktivitas belajar siswa dalam pembelajaran tematik di siklus II dapat dilihat pada diagram 4 di bawah.

Diagram 4. Rekapitulasi Hasil Observasi Aktivitas Siswa Siklus II

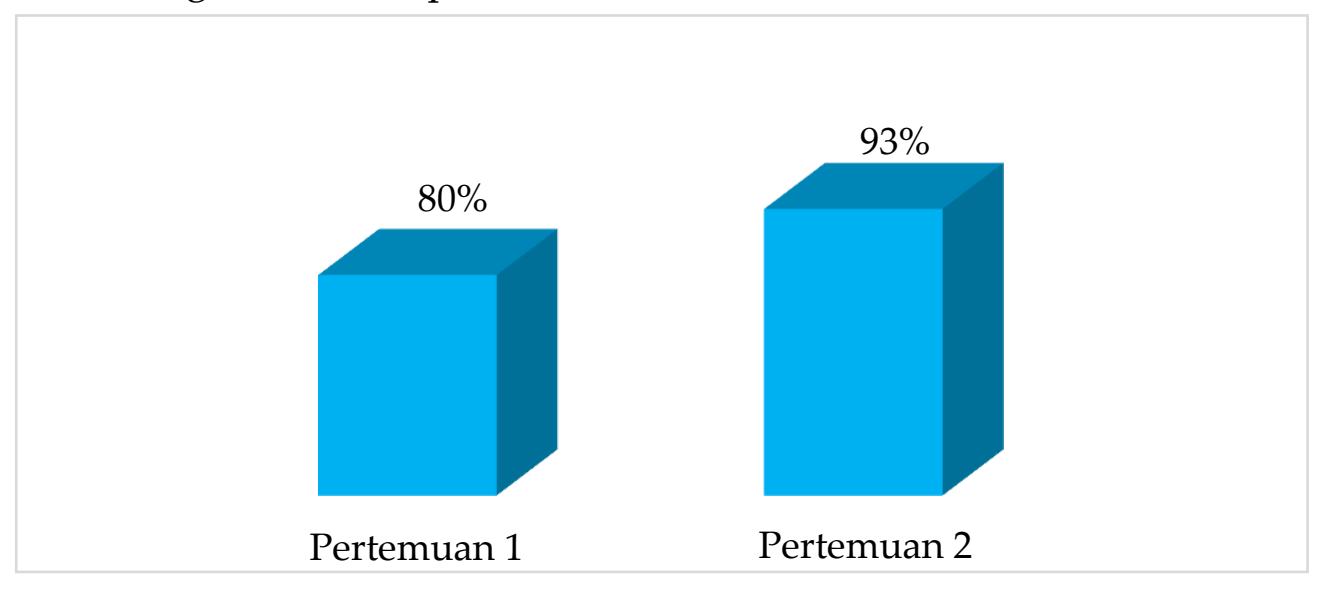

Diagram 4 di atas terlihat bahwa hasil observasi aktivitas siswa pada siklus II memperoleh nilai rata-rata sebesar $86,5 \%$ dan berada pada kategori baik. Artinya siswa 
sudah terlihat aktif dalam kegiatan pembelajaran tematik dengan menggunakan model make a match. Jadi kesimpulannya ialah aktivitas belajar siswa di siklus II dalam pembelajaran tematik melalui model make a match berlangsung dengan baik.

Adapun rekapitulasi hasil observasi aktivitas guru dan siswa dalam pembelajaran tematik subtema rukun dalam perbedaan melalui model make a match dapat dilihat pada tabel 1. di bawah.

Tabel 1. Rekapitulasi Hasil Observasi Aktivitas Guru dan Siswa

\begin{tabular}{|c|c|c|c|}
\hline No. & Proses Pembelajaran & Siklus I & Siklus II \\
\hline 1. & Observasi aktivitas guru & $57,5 \%$ & $89 \%$ \\
\hline 2. & Observasi aktivitas siswa & $62,5 \%$ & $86,5 \%$ \\
\hline \multicolumn{2}{|l|}{ Rata-rata } & $60 \%$ & $87,7 \%$ \\
\hline
\end{tabular}

Tabel 1 di atas dapat dilihat bahwa hasil observasi aktivitas guru di siklus I memperoleh nilai $57,5 \%$ dan di siklus II $89 \%$. Hal tersebut menunjukkan adanya peningkatan aktivitas guru dalam upaya meningkatkan minat belajar siswa pada pembelajaran tematik menggunakan model make a match sebesar 31,5\%. Kemudian hasil observasi belajar siswa di siklus I memperoleh $62,5 \%$ dan di siklus II $86,5 \%$. Ini berarti terjadi peningkatan dari siklus I ke siklus II sebesar $24 \%$.

Selanjutnya hasil belajar siswa yang diukur dari uji tes dalam proses pembelajaran tematik subtema rukun dalam perbedaan di kelas 6 semester ganjil T.P 2019/2020 MIN 3 kota Medan melalui model make a match. Data hasil belajar siswa melalui penerapan model make a match pada pembelajaran tematik dapat dilihat pada diagram 5 di bawah.

Diagram 5. Rekapitulasi Hasil Belajar Siklus I

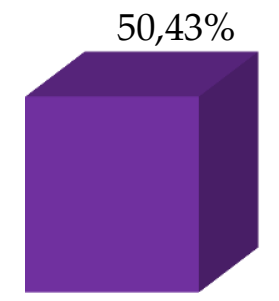

Pertemuan 1

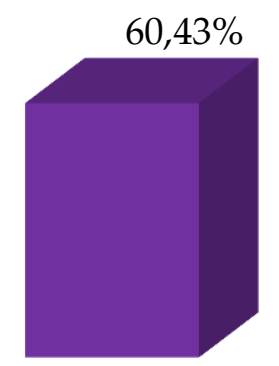

Pertemuan 2 
Diagram di atas menjelaskan bahwa persentase hasil belajar siswa pada pembelajaran tematik subtema rukun dalam perbedaan melalui model make a match di siklus I memperoleh nilai rata-rata sebesar $55,43 \%$ dan berada pada kategori cukup. Sedangkan di siklus II mengalami pelonjakan. Berikut persentase data dapat dilihat pada diagram 6 di bawah.

Diagram. 6 Rekapitulasi Hasil Belajar Siklus II

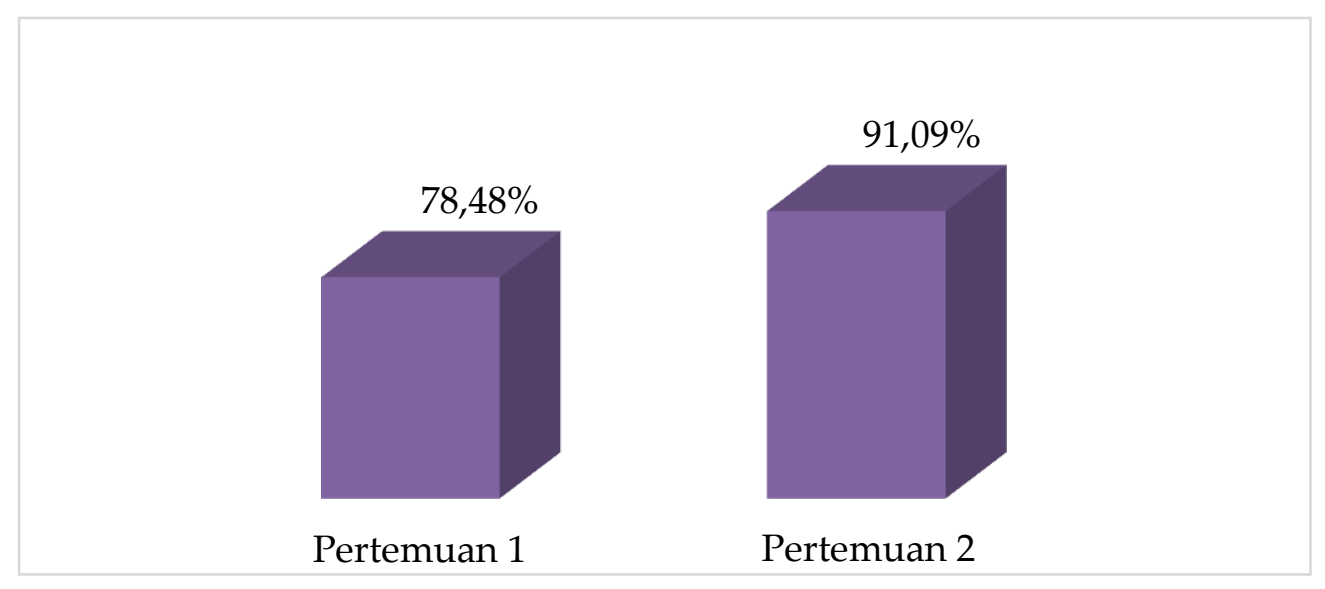

Berdasarkan data dari diagram 6 di atas terlihat bahwa hasil belajar siswa terhadap pembelajaran tematik subtema rukun dalam perbedaan kelas 6 MIN 3 kota Medan memperoleh nilai rata-rata sebesar $84,78 \%$ dan berada pada kategori sangat baik. Hal ini berarti bahwa hasil belajar siswa pada pembelajaran tematik sudah mengalami peningkatan sesuai dengan tujuan dan harapan yang ingin dicapai. Oleh karena itu, maka dapat disimpulkan bahwa selesai diterapkannya model make a match pada proses pembelajaran tematik, model ini mengandung pengaruh terhadap peningkatan hasil belajar siswa, artinya model ini sangat baik dan penting untuk diterapkan di dalam kelas maupun di luar kelas.

Selanjutnya data yang diperoleh dari hasil wawancara kepada siswa di siklus I terkait hasil belajar, bahwa isi tanggapannya ialah siswa kurang paham/ ngerti dalam menyelesaikan soal yang diberikan guru. Selain itu siswa masih bingung cara melakukan model make a match. Sedangkan hasil wawancara di siklus II mendapat tanggapan yang positif dari siswa bahwa model make a match mampu mengajak siswa belajar sambil bermain, selain itu mampu meningkatkan hasil belajar juga.

\section{Pembahasan}

Model make a match melibatkan siswa secara langsung dalam proses pembelajaran sehingga siswa lebih banyak memberikan perhatian dan lebih menikmati proses pembelajaran. Hal tersebut dikarenakan cara ini dikemas seperti sebuah 
permainan dengan tidak membuang inti dari proses pembelajaran tersebut (Juhji, 2017, h. 14). Model make a match juga dapat membuat siswa antusias dalam mengikuti pembelajaran, karena model ini dirancang seperti mainan dan tanpa disadari siswa belajar sambal bermain. Konsep yang diserap siswa akan tertanam dengan baik di memori sehingga mampu mengingat dan membangun daya nalar. Selain itu model make a match menjadi salah satu solusi untuk meningkatkan pemahaman siswa, sehingga mampu meningkatkan hasil belajar tematik siswa. Sebab, model make a match mampu melibatkan siswa ikut aktif dalam kegiatan pembelajaran.

Penelitian ini memfokuskan pada peningkatan hasil belajar siswa dengan menerapkan model make a match pada pembelajaran tematik kelas 6 MIN 3 kota Medan. Atas dasar analisis data yang ditemukan dalam kegiatan selama proses pembelajaran berlangsung dimulai dari siklus I dengan menerapkan model make a match, terlihat adanya peningkatan hasil belajar siswa dengan rata-rata hasil observasi aktivitas belajar siswa siklus I sebesar 62,5\%. Namun, hasil observasi aktivitas belajar siswa tersebut belum mencapai sesuai harapan yang diinginkan. Maka perlu ditindak lanjut dengan melakukan siklus II, guna memperbaiki sistem yang belum tercapai di siklus I. Penerapan model make a match di siklus I masih ditemukan kekurangan seperti: (1) siswa kurang terlihat aktif dalam kegiatan belajar, (2) kerja sama dalam kegiatan belajar belum terbangun dengan baik. Hal ini terlihat dari aspek berdiskusi/ berpartisipasi dalam kelompok yang termasuk pada kriteria sedang. Selanjutnya siswa dalam satu kelompok masih kurang percaya diri untuk bertanya dengan teman pasangannya.Untuk itu perlu dilakukannya tindak lanjut di siklus II.

Setelah dilakukannya siklus II, hasil observasi aktivitas siswa pada pembelajaran tematik dengan menggunakan model make a matchmengalami peningkatan dengan memperoleh nilai rata-rata sebesar $86,5 \%$. Dari nilai tersebut terlihat bahwa para siswa memiliki minat dan motivasi belajar yang tinggi. Hal ini ditemukannya banyak siswa yang antusias dalam menerapkan model make a match dan bersemangat mengerjakan tes dari guru.

Dari analisis data pengamatan aktivitas guru dapat dilihat upaya guru untuk meningkatkan hasil belajar siswa di siklus II mencapai nilai rata-rata nilai $89 \%$.Hal ini sangat berperan penting dalam meningkatkan aktivitas belajar siswa. Oleh sebab itu, dalam proses pembelajaran guru perlu menggunakan model pembelajaran yang variatif dan inovatif sehingga minat yang ada pada diri siswa muncul, dikarenakan ada keingintahuan yang tinggi. Oleh karena itu, melalui penerapan model make a match pada pembelajaran tematik subtema rukun dalam perbedaan ternyata dapat membuat 
siswa aktif saat memahami materi pelajaran, inilah yang dapat mempengaruhi hasil belajar siswa agar melonjak.

Hal ini diperkuat dengan hasil penelitiannya Ginting (2016) yang menyatakan bahwa penerapan pembelajaran dengan menggunakanmodel make a match dapat meningkatkan hasil belajar siswa pada mata pelajaran IPS di kelas V SD Negeri 106163 Bandar Klippa sebesar 60\% di siklus I, kemudian diterapkan kembali pada siklus II dan mengalami peningkatan menjadi $84 \%$. Selain itu model ini bukan hanya meningkatkan hasil belajar saja, tetapi juga mampu meningkatkan motivasi belajar. Hal ini pernah diungkapkan dari hasil penelitian yang dilakukan oleh Lestari \& Muhajir (2019) yang menyatakan bahwa setelah diterapkannya model pembelajaran make a match telah terjadi peningkatan motivasi belajar siswa pada pelajaran IPA tema 5 kelas V SDN Jatingaleh 01 semarang. Hasil penelitian serupa juga dilakukan oleh Khoirudin (2019) yang memaparkan bahwa model pembelajaran make a match dapat meningkatkan motivasi dan hasil belajar siswa kelas VI SDN 1 Guwotirto dengan memperoleh nilai di siklus I sebesar 69,23\% menjadi 87,69\%. Dari paparan hasil penelitian yang sudah dilaksanakan sebelumnya, maka dapat diberikan kesimpulan bahwa penerapan model pembelajaran make a match mampu meningkatkan hasil belajar maupun motivasi belajar siswa khususnya pada pembelajaran tematik di sekolah dasar.

\section{PENUTUP}

Berdasarkan perolehan hasil penelitian tindakan kelas yang sudah dilakukan selama dua siklus yang terdiri dari 4 pertemuan. Mengenai implementasi model make a match pada pembelajaran tematik dengan tema persatuan dalam perbedaan, subtema rukun dalam perbedaan di kelas 6 semester ganjil tahun pelajaran 2019/2020 MIN 3 kota Medan. Dari hasil data yang diperoleh menunjukkan bahwa terlihat adanya peningkatan hasil belajar siswa. Hasil tersebut dilihat dari analisis data aktivitas guru siklus I pertemuan dengan nilai 50\% dan pertemuan 2 dengan nilai $65 \%$. Maka dapat disimpulkan bahwa rata-rata perolehan data aktivitas guru pada siklus I ialah 57,5\%. Sedangkan di siklus II perolehan hasil pada pertemuan 1 dengan nilai $86 \%$ dan pertemuan 2 dengan nilai 92\%. Maka dapat disimpulkan rata-rata perolehan data di siklus II ialah $89 \%$. Selanjutnya pada analisis data dari aktivitas siswa di siklus I pertemuan 1 dengan nilai $55 \%$ dan pertemuan 2 dengan nilai $70 \%$, jadi dapat disimpulkan rata-rata perolehan data pada aktivitas siswa siklus I ialah 62,5\%. Sedangkan di siklus II perolehan hasil pada pertemuan 1 dengan nilai $80 \%$ dan pertemuan 2 dengan nilai 93\%, maka dapat disimpulkan rata-rata perolehan data pada aktivitas siswa siklus II ialah 86,5\%. 
Kemudian data hasil belajar siswa perolehan nilai pada siklus I pertemuan 1 sebesar 50,43\% dan pertemuan 2 sebesar 60,43\%, maka dapat disimpulkan rata perolehan pada siklus I ialah 55,43\%. Sedangkan di siklus II perolehan nilai pada pertemuan 1 sebesar 78,48\% dan pertemuan 2 sebesar 91,09\%, maka dapat disimpulkan rata-rata perolehan data pada hasil belajar siswa siklus II ialah 84,78\%. Maka demikian, penerapan model make a match pada pembelajaran tematik tema persatuan dalam perbedaan subtema rukun dalam perbedaan di kelas 6 semester ganjil tahun pelajaran 2019/2020 mampu meningkatkan hasil belajar siswa di MIN 3 kota Medan.

Kemudian hasil wawancara mendapat angin segar, karena tanggapan yang diberikan siswa dan guru terhadap model make a match mampu meningkatkan hasil belajar tematik subtema rukun dalam perbedaan.

\section{DAFTAR PUSTAKA}

Aliputri, D. H. (2018). Penerapan Model Pembelajaran Kooperatif Tipe Make A Match Berbantuan Kartu Bergambar Untuk Meningkatkan Hasil Belajar Siswa. Jurnal Bidang Pendidikan Dasar (JBPD), 2(1A), 70-77. http: ejournal.unikama.ac.id/index.php/JBPD.

Arikunto, S. (2005). Dasar-Dasar Evaluasi Pendidikan. Jakarta: Bumi Aksara.

Ginting, M. (2016). Meningkatkan Hasil Belajar Siswa dengan Menggunakan Model Pembelajaran Make a Match Pada Mata Pelajaran IPS di Kelas V SD Negeri 106163 Bandar Klippa. Elementary School Journal PGSD FIP UNIMED, 5(2), 49-55. https:/jurnal.unimed.ac.id/2012/index.php/elementary/article/view/4468/3912.

Harahap, N. (2017). Efforts to Increase Activity and Results of Math Students Learning Through Aplication Model Make a Match Type Cooperative Learning Primary Class VI SD Negeri 168432 Tebing Tinggi. Elementary School: Journal PGSD FIP UNIMED, $\quad$ 7(3), 453-466. https://jurnal.unimed.ac.id/2012/index.php/elementary/article/view/8184/6827.

Isnarofik, M. B. (2017). Upaya Meningkatkan Rasa Ingin Tahu dan Prestasi Belajar Ilmu Pengetahuan Alam Materi Pembentukan Tanah Melalui Model Pembelajaran Make a Match. Dinamika: Jurnal Ilmiah Pendidikan Dasar, 9(1), 42-46. Retrieved from http://jurnalnasional.ump.ac.id/index.php/Dinamika/article/view/3860/2299\#.

Juhji. (2017). Model Pembelajaran Kooperatif Tipe Make a Match dalam Pembelajaran IPA. Jurnal Primary, http://jurnal.uinbanten.ac.id/index.php/primary/article/view/313/312.

Kaharuddin, A. (2018). Keefektifan Model Make A Match dalam Pembelajaran Matematika Siswa Kelas VI Sekolah Dasar. Jurnal Pendidikan dan Pembelajaran Dasar, 11(1), 13-23. http://ejournal.uin- 
malang.ac.id/index.php/madrasah/article/view/5563/pdf.

Khoirudin, M. (2019). Model Pembelajaran Make a Match Untuk Meningkatkan Motivasi dan Hasil Belajar Mendeskripsikan Nilai Juang Pancasila Sebagai Dasar Negara Pada Siswa Kelas VI SDN 1 Guwotirto Tahun Pelajaran 2013/2014. Elementary School, 6(2), 190-195.

https://journal.upy.ac.id/index.php/es/article/view/279.

Kunandar. (2011). Langkah Mudah Penelitian Tindakan Kelas Sebagai Pengembangan Profesi Guru. Jakarta: Rajawali Pers.

Lestari, A. A., \& Muhajir, H. J. S. (2019). Keefektifan Model Make a Match Terhadap Motivasi Belajar Siswa Pada Pelajaran IPA Tema 5 Kelas V SDN Jatingaleh 01 Semarang. $6(2)$ Elementary School, 139-144.

https://journal.upy.ac.id/index.php/es/article/view/273.

Murni, W. (2010). Evaluasi Pembelajaran Kompetensi dan Praktik. Yogyakarta: Nuha

Litera. Salim, \& Syahrum. (2012). Metodologi Penelitian Kualitatif. Medan:

Citapustaka Media.

Siregar, P. S., \& Hatika, R. G. (2019). Ayo Latihan Mengajar: Implementasi Kurikulum 2013 di Sekolah Dasar (Peerteaching dan Microteaching). Yogyakarta: Deepublish.

Tiyasa. (2018). Pengaruh Cooperative Learning tipe Make a Match Terhadap Hasil Belajar Matematika Siswa Sekolah Dasar. Jurnal Inovasi Pendidikan Dasar, 4(1), $13-$

20. http://jipd.uhamka.ac.id/index.php/jipd/article/view/75/36.

Wandy. (2017). Metode Pembelajaran Make a Match Untuk Meningkatkan Hasil Belajar Bahasa Indonesia Siswa Sekolah Menengah Pertama. Jurnal Ilmu Pendidikan Sosial, Sains, Dan Humaniora, 3(1), 109-116. 